\title{
A TERM FOR ROME AND BYZANTIUM IN THE PERSIAN TEXTS
}

\author{
Daryoosh Akbarzadeh \\ ICHTO. Tehran, Iran
}

Resumen: El Kush-nameh, uno de los textos islámicos más famosos, que trata de las relaciones históricas entre Irán y Silla, fue escrito por el gran erudito iraní Iran-Shan ibn Abal-khayr en el año 501-04 de la Hégira (1108-11 AD). Referencias al Kush-nameh y al Kush se conocen a partir otros escritos islámicos. El Kush-nameh menciona Frwm, que está ubicada en el norte (oeste) de Irán, como un topónimo chino. El término deriva del parto frwm y generalmente se expresa como hrwm en persa medio. Farvaneh, la designación de la ciudad construidda para el Kush en el Kush-nameh, puede ser reconocida como una modificación del persa medio Brwm/frwm (Roma/Bizancio), que aparece aquí como Farvaneh, y no Forunneh, debido a razones métricas.

Palabras clave: Kush-nameh, Frwm, Roma y Bizancio, Período Persa Medio.

Abstract: The Kush-nameh, one of the most famous Islamic epic texts, dealing with the historical relations between Iran and Silla, was written by the great Iranian scholar Iran-Shan ibn Abal-khayr in 501-04 Hegira (1108-11 AD). References to the Kush-nameh and to Kush are known from other Islamic writings.

The Kush-nameh mentions Frwm, which is located to the north (west) of Iran, as a Chinese toponym. The term derives from Parthian frwm and is generally rendered hrwm in Middle Persian. Farvaneh, the designation of the city built for Kush in the Kush-nameh, may be recognized as a modification of a Middle Persian $\beta r w m / f r w m$ (Rome/Byzantium), which is rendered here as Farvaneh, and not Foruneh, owing to metric reasons.

Keywords: Kush-nameh, Frwm, Rome and Byzantium, Middle Persian Period.

Recibido: 18.10.2012 - Aceptado: 16.12.2012

Correspondencia: DARYoosh AKBARZADEH, damavandiiranmihr@yahoo.com Assistant professor of Ancient and Middle Iranian Languages and Linguistics, Cultures. Address: Shahrak Apadana, Bloc. 39, $2^{\text {nd }}$ Entrance, n ${ }^{\circ}$ 5, Azadi Sque., Tehran, Iran. Mobile: ++98-09123050132 
rchaeology, texts, and oral traditions preserved by mythological $\Delta$ narratives confirm that the relations of Iran simultaneously with 1 the West and China, via both the Silk Road and the Persian Gulf (Akbarzadeh 2008), went at least as far back as the reign of Mihrdad II (123-87 $\mathrm{BC}$ ) in the Arsacid period. From the Iranian side, especially valuable testimony for Iran's far-reaching historical, religious, and artistic contacts with, on the one hand, China, Japan, Korea in South and Southeast Asia in the East and, on the other hand, the Greco-Roman and Byzantine worlds in the West, is provided by important Post-Sasanian geographical-historical texts, which are extensively affected, in turn, by pre-Islamic oral and written sources. Sometimes, details that became garbled in the transmission may also be elucidated with the help of Middle Iranian writings, such as Sogdian (northern) texts and Zoroastrian Pahlavi (southern) texts. A case in point is an archaic toponym, Farvaneh, which is referred to China in the Kush-nameh, but which properly belonged, as it is argued here, in the Greco-Roman/Byzantine sphere.

The Kush-nameh, one of the most famous Islamic epic texts, dealing with the historical relations between Iran and Silla, was written by the great Iranian scholar Iran-Shan ibn Abal-khayr in 501-04 Hegira (1108-11 AD). References to the Kush-nameh and to Kush are known from other Islamic writings (cf. Matini 1998; Zayn al Akhbar 2006).

In the introduction to the work, Iran-Shan explains how he came to write this epic text using an earlier written source. One of the nobles of city, who was his friend, had a prose text related to China and offered it to Iran-Shan to versify it. The text, which Iran-Shan accepted to put in verse, was the tale of Kush:

127. Zamaneh chu karam delaray kard

128. Yeki mehtari dashtam man be shahr

132. Mara goft agar ray dari bar in

133. Ke har kas an ra be khanad be hush delam dastani degar kard kea $\mathrm{z}$ danesh o mardomi dasht bahr yeki dastani daram az shah-e Chin basi bahreh bar darad az kar-e Kush 
134. Bedidam man in nameh-ye sudmand sirasar hameh danesh o ray pand

"I had a noble friend in my city who was a knowledgeable and important person. He told me:"I give you a written text related to China, if you plan to write a new book ..."

The epic written by Iran-Shan is divided into two parts. The first part, ending at verse 918, focuses on tales related to the Greeks, Romans and Byzantines, such as stories about Alexander's visit to Central Asia and India and the Christians, and includes references to iranized western names (e.g., Hippokrates, Plinius) and texts (e.g., Galenos' text) (Matini 1998). In the second part (verses 919-10129), Iran-Shan tells, generation by generation, the story of a community of Iranians who were in China since Jamshid's time. He explains in detail the situation of these Iranians in China, their escape to Basila (>Silla, Akbarzadeh 2013), and their friendship with the king of Silla, Tayhur. Historical events mentioned in the text appear to be confused occasionally with mythological beliefs current in ancient Iran. The materials range widely across the Parthian-Kushan, Greek, Roman, Byzantine, Sasanian and, finally, Islamic periods, while the proper name Kush also recalls, of course, the Kushan empire.

Kush, the hero of text, received the kingdom of China, in place of his father (also named Kush), and decided to build a city and make his statue so that people would worship him:

6654. khosh amadsh, benshast bar kuh-e zharf pas afgand az an shahr sangi shegarf

6655. basi ranj bordand zan char mah 6656. rokhamin yeki sang bar pay kard 6657. kaf das tow baz kardeh ze ham sar-e kongrash bar kashid ow be mah sar-e paykar-e khish ra jay kard

bar ow bar nebeshteh yeki bish o kam 6658. ke in chehreh-ye kush garden-kash ast ke hengam paygar chun atash ast... 6664. nihadand Kushan bedan shahr nam 6665. ke Chini hami khandash Farvaneh 6666. sar-e sal farmudashan ta hameh 6667. parastesh konan pish an paykarash bar-avardeh-ye Kush joyandeh kam be anbuh shahri ze bar o beneh shaved pish an pil-e mardom rameh setayesh namayad bar afsarash

"Kush ordered to build a city by the nearest mountain. He ordered the people to complete formidable tasks for the 
construction of such a big city. He also ordered a statue of his to be placed inside this city, with an inscription on the hand of the statue reading: 'This is the statue of Kush, who is unique in times of combat and killed many kings'...People called this city Kushan, meaning that it was founded by Kush. This city is known as Farvaneh in the Chinese language, a populous city. He also ordered that people worship his statue."

We know that in Sogdian texts the Romans and Byzantines are called $\beta$ rwm (Frūm) (Gharib 2004, no. 2712, 2713, 2788, 2789, 3934, 3935; Gershevitch 1954). The term derives from Parthian frwm and is generally rendered hrwm in Middle Persian. Farvaneh, the designation of the city built for Kush in the Kushnameh, may be recognized as a modification of a Middle Persian $\beta$ rwm/frwm, which is rendered here as Farvaneh, and not Foruneh, owing to metric reasons.

I believe that it is possible to restore the same toponym in two further instances. In the first instance, in a passage of his work, entitled About the Commanders of the Roman Troops, Ibn Balkhi (Gharehchanlu 1992) mentions that "Constantinople is the biggest city of Rome [i.e., of the Roman world] and its center of commanders, and this city [i.e., Constantinople] is called Balozrōm". Given the similarity between $\dot{j}$ and $g$ in the Persian writing system, it seems that the first part of the city name (Ba/oz: the northern Middle Persian $\beta$ becomes an $f$ or a $b$ in modern Persian) can be a miswriting for $B W /$ وبر, rather than $B \delta /$, by copyist $(s)$. At the same time, the second $o$, following $r$, can induce a further $o$ in the first part because of assimilation (cf. be > bodo = 'run', ast > ostokhan = 'bone'). In this case, a toponym, such as بوروم/ن, recalls Farvaneh/Forun > Frum/n.

In the second instance, in Masudi's (Payandeh 2011) writings, entitled Nazareth Roman Kings it is stated that:

"The first king was Constantine. He built the city of Constantinople on the seacoast in the third year of his reign. This city is located in Byzantium, and he selected it as his capital. The city was named after him and Roman kings resided there. To date the Romans refer to it as Bolun and, when they want to indicate that it is a capital, as Estan Bolun."

I take Bolun as a modified form of Folun (> frwm). In this case, Estan Bolun would be "Eastern Frwm [i.e., eastern Rome = Constantinople/Byzantium]". 
The surprising reference to Farvaneh as a city in China in the Kush-nameh may be possible to understand with reference to the impact of ancient Iranian perceptions concerning the configuration of the world through the ages. According to the Avesta, the world is subdivided into seven mythological "climates/countries/geographical directions".

These mythological subdivisions of the world take a quasi-historical significance in Sasanian texts. In late Sasanian and Post-Sasanian texts, moreover, country names that are associated in the Avesta with geographical parts of the world are flatly used some times in place of "actual" geographical directions. This transposition is a normal occurrence in the case of China (which is associated with one of the mythological "climates/directions") and results in a confusion of the actual boundaries of the Iranian and Chinese regions which is perpetuated by Islamic writers.

Examples are offered by the uses of terms, such as čyn and čynst'n, in the Bundhišn. In one instance (MS.TD2 1978), it is stated that:

"One may reckon: who are in the Iranian (Aryan) lands, and who are in the non-Iranian lands; on the other hand, who are in Tur' $s$ land, who are in Salm's land, meaning Rome['s territory], who are in the Sin's land, meaning Činestān, who are in the Sind land ..."

Elsewhere, we are told that "the mountain of Aspōrz is up of Činestān, [in the way of] Dāybād to Pārs, Pahargar to Xwarāsān..." (Ibd.8) or: kōf ī syāhōmand, kōf ì varf-ōmand ān īš-ān Kāwul, ān kustagīhā u-š rust ēstād tā ō $\bar{i}$ kust $\bar{\imath} \check{C}_{\bar{e}}$ "the mountain of Syah-omand and the mountain of Varf-omand which are located [near] Kabul, spread from there [i.e., Kabul] toward the China 'climate'/'direction' " (or, perhaps, "the mountain of Syah, which is the keeper of the snow, is located [near] Kabul and spreads from there [i.e., Kabul] toward the China 'climate'/'direction' " (Ibd.79) (see, Akbarzadeh 2010).

Judging by these examples, 'China' could be used sometimes as a country name and at other times as a reference to an east 'climate'/'direction', like čìnestān and kust i Čèn. This interpretation is further corroborated by references

${ }^{1}$ This division is also attested in later texts. In the description of Mojmal al Tavarikh (Unonymous 2009), for instance, these seven "climates" are:

"(the) Climate of Iran, (the) Climate of Rome, (the) Climate of Africa, (the) Climate of Arab, Climate of India, Climate of China, Climate of Turk". As the same author notes, "the Climate of Iran is in the center of world" and "the first Climate [that of China] is located in the East." 
in Islamic texts, wherein the expression China climate and Chinese Batā $d^{\prime}$ is used instead of činestān (Akbarzadeh 2008). See, for instance: "He (Faridun) gave Č̀nestān and the East to Tuj” (Ba'lami 2008) and: baraft ān brādar za Rum,in za Chin be zahr andar āmixteh angabin

"This brother went from Rome [i.e., from the West] and that brother went from China [i.e., from the East]. Both carried on them poison mixed with honey" (Firdowsi 2002, Vol. I., 93; passim).

In a number of Post-Sasanian texts, the same east 'climate', that of China (and Tibet), includes Sogdiana and parts of the Great Khorasan Highway. Thus, according to Ibn Ru/asteh (Gharehchanlu 1987):

"[The fourth [i.e., China] climate] starts from the east. After Tibet and parts of Khorasan, the main cities are: Farghaneh, Khojand, Osrushoneh, Samarqand, Bokhara...Hamadan, Nihavand..."

A similar perception occurs in Maghdasi (Shafie Kadkani 2008), who notes that: " $\mathrm{t}]$ he fourth [i.e., China] climate starts from the east. From Tibet and Khorasan, Gorgan, Tabaristan.... and cities of Khorasan: Faraghaneh, Khojand, Osrushoneh, Samarqand, Bokhara, Balkh... Nihavand..." (cf. Masudi: 2009, 31).

The references to China (as a 'climate') as encompassing Sogdiana (i.e. Farghaneh, Khojand) and parts of the Great Khorasan Highway implies a merging of the boundaries of the Chinese and Iranian regions.

This merging of the boundary of the China 'climate' with eastern and northern Iranian regions, thus, along the path of the Silk Road by means of which Rome and Byzantium, Iran, and China had long had contact with one another, may be the main reason why the Kush-nameh mentions Frwm (i.e., Rome/Byzantium), which is located to the north (west) of Iran, as a Chinese toponym. This would also mean, however, that by the time of the composition of the Kush-nameh, the Iranian origins of the toponym Frwm had been forgotten. Historical oblivion and geographical confusion are probably to understand in this instance against the backdrop of the major historical developments that followed the collapse of the Sasanian Empire and the shakedown of Iranian authority in parts of central Asia, as far as China, with the advent of Islam and subsequent Chinese and Turkish invasions in Central Asia. 


\section{Bibliography}

1. Afarinesh va Tarikh. (2008). Motaher ibn Taher Maghdasi. $2^{\text {nd }}$. Edition. Vol. I-II. by M. R. Shafie Kadkani. Tehran: Agah.

2. Akbarzadeh, D. (2008). "Korea in the Medieval Persian Manuscripts and Korea- Iran Relation". International Conference on Iran-Silla Historical relations. 125-147, Seoul: Hanyang Univ. Press.

3. Akbarzadeh, D. (2010). "Hindugan of Bundhishn". Iranica Antiqva, XLV, 419-426, Ghent: University of Ghent.

4. Akbarzadeh, D. and Lee H.S. (2013). "Silla or Basilla". International Journal of Intangible Heritage. (in print). Seoul: The National Folk Museum of Korea Journal.

5. Al Alaegh al Nafiseh. (1987). Ahmad ibn Omar ibn Rusteh. By H. Gharehchanlu. Tehran: Amir Kabir.

6. Al Tanbiyata va al Ashraf. (2011). Abolhasan Ali ibn Hosein Masudi. $4^{\text {th }}$ edition. translator: A. Payandeh. Tehran: Elmi-Farhangi.

7. Gershevitch, I. (1954). A Grammar of Manichean Sogdian. Oxford: B. Blackwell.

8. Gharib, B. (2004). Sogdian Dictionary (Sogdian, English, Persian). $2^{\text {nd }}$. Edition. Tehran: Farhangan.

9. Iranian Bundhishn (MS.TD2, Bundhišn). (1978). Part I. edit by Jamasp Asana, M. Navabi, M. Tavousi, Shiraz: Univ. of Pahlavi.

10. Kush-nameh. (1998). Iranshan ibn Abalkhayr. by J. Matini, Tehran: Elmi.

11. Masalek va-Al-Mamalek Ibn Balkhi. (1992). Translator: H. Gharehchanlu, Tehran: Motarjem.

12. Matini (1998). see Kush-nameh.

13. Mojmal al Tavarikh va -al- Qasas. (2009). Unonymous. by Ml. Bahar. Tehran: Asatir.

14. Moruj-al-Zahhab va Moaden -al- Johar. (2009). Ali ibn Hosein Masudi. Translation: A. Payandeh, Tehran: Elmi-Farhangi.

15. Shah-nameh -E Firdowsi. (2002). A. E. Bertels and others I-IX Vols. (in VII Vols.). $2^{\text {nd }}$. Edition, Tehran: Hermes.

16. Tarikh-e Ba'lami. (2008). M. Jarir Tabari. Translator: Abu Ali Ba'lami. By Ml. Bahar and M. Parvin Gonabadi. Tehran: Hermes.

17. Zayn al Akhbar. (2006). Abu Saeed A. ibn Zahhak ibn M. ibn Gardizi. By R. Rahimzadeh-Malek, Tehran: Asar-e Mafakher-e Farhangi. 